\title{
LOCAL INSTITUTIONS AND NATURAL RESOURCE MANAGEMENT IN THE SOUTH TONGU DISTRICT OF GHANA: A CASE STUDY
}

John E. Koku* and Jan-Erik Gustafsson

Royal Institute of Technology, Sweden

This paper draws on secondary and primary data derived from a field survey undertaken in Torsukpo and Agbogbla communities in the South Tongu District of Ghana to discuss possibilities of enhancing the roles of local institutions in resource management. Key issues addressed in the paper include

(i) limitations which share cropping (abunu-abusa) as a local social institutional arrangement places on tenant farmers and (ii) the role of the District Assembly with specific reference to policy provisions placed at its disposal that could be used to formulate co-operative strategies that may help mobilize and empower the local people for effective natural resources management. To complement efforts in this direction, the paper also highlights some possible ways in which NGOs could play more effective roles in facilitating development process in the district. Copyright (C) 2003 John Wiley \& Sons, Ltd and ERP Environment.

\footnotetext{
* Correspondence to: J. E. Koku, Department of Land and Water Resources Engineering, Royal Institute of Technology (KTH), Brinellvagen 28, SE-100 44, Stockholm, Sweden.

E-mail: koku@aom.kth.se

Contract/grant sponsor: Sida (SAREC).
}

Copyright @ 2003 John Wiley \& Sons, Ltd and ERP Environment.
Received 5 April 2001

Revised 23 October 2001

Accepted 4 December 2001

\section{INTRODUCTION}

$\mathrm{T}$ he role of institutions in natural resource management and rural development has received increased attention in recent times and has been widely discussed (Gustafsson, 1984; Mearns 1995; Uphoff, 1992; Appendini et al., 1999; Boesen et al., 1999; Hinchcliffe et al., 1999; Shah and Shah, 1999; Koku and Gustafsson, 2001). While this observation holds true in a general sense, the role of local institutions is of particular interest to discussions concerning rural Ghana, where livelihood is mostly dependent on the use of natural resources. Experiences gathered from studies and development work tend to show that in most rural areas the governing (regulatory) mechanisms of local institutions have often had an influence on sustainable natural resource use. In some communities in Ghana, certain local institutions ${ }^{1}$ (especially those relating to customary land tenure arrangements) have been reported to create structures that restrict access to natural resources, while some also

${ }^{1}$ Institutions are here as patterns of behaviour between individuals and groups in society. They are regularized patterns of behaviour that emerge from the underlying structures or sets of rule in use (see Leach and Mearns, 1996). 
give rise to a tendency of overexploitation of land among tenant farmers. A case in point is the recent study among the Yensiso, Amanase and Sekesua farmers in Ghana (Gyasi, 1997, p. 87).

Miller et al. (1996) have studied the indigenous land tenure system in Zanlergu in the Upper East region of Ghana, and noted among other things that land rental (which is an integral part of the prevailing customary tenancy arrangement) creates disincentive to long term investment in land. In particular, they observed that 'Where land is rented, the ultimate right of repossession and, more immediately, control over trees and other perennial features on the land, remain under the control of the original owner;... and further that, under the prevailing tenancy arrangement women's rights to land are secondary and contingent on their relationship to male kin' (pp. 119-120). The consequences of such limitations can be baneful, sometimes giving rise to exploitative behaviour by those deprived, which undermines sound resource use.

The South Tongu District of Ghana (Figure 1) is not excluded from the above general observation (cf. Koku, 2001). Being an agrarian society, the livelihood of its people depends largely on subsistence farming, petty trading and fishing. Official reports on the socio-economic status of the district indicate that poverty continues to deepen (South Tongu District Assembly, 1996). Moreover, environmental change, taking the form of deforestation and sheet erosion coupled with fluctuating and declining rainfall patterns (Figure 2), continues to threaten the productivity of its landscapes, thus necessitating concerted action. To promote sound environmental planning and natural resources use among the communities, there is an ongoing crusade for tree planting. As part of the crusade, agro-forestry and woodlots are being popularized among the local farmers. Lately,

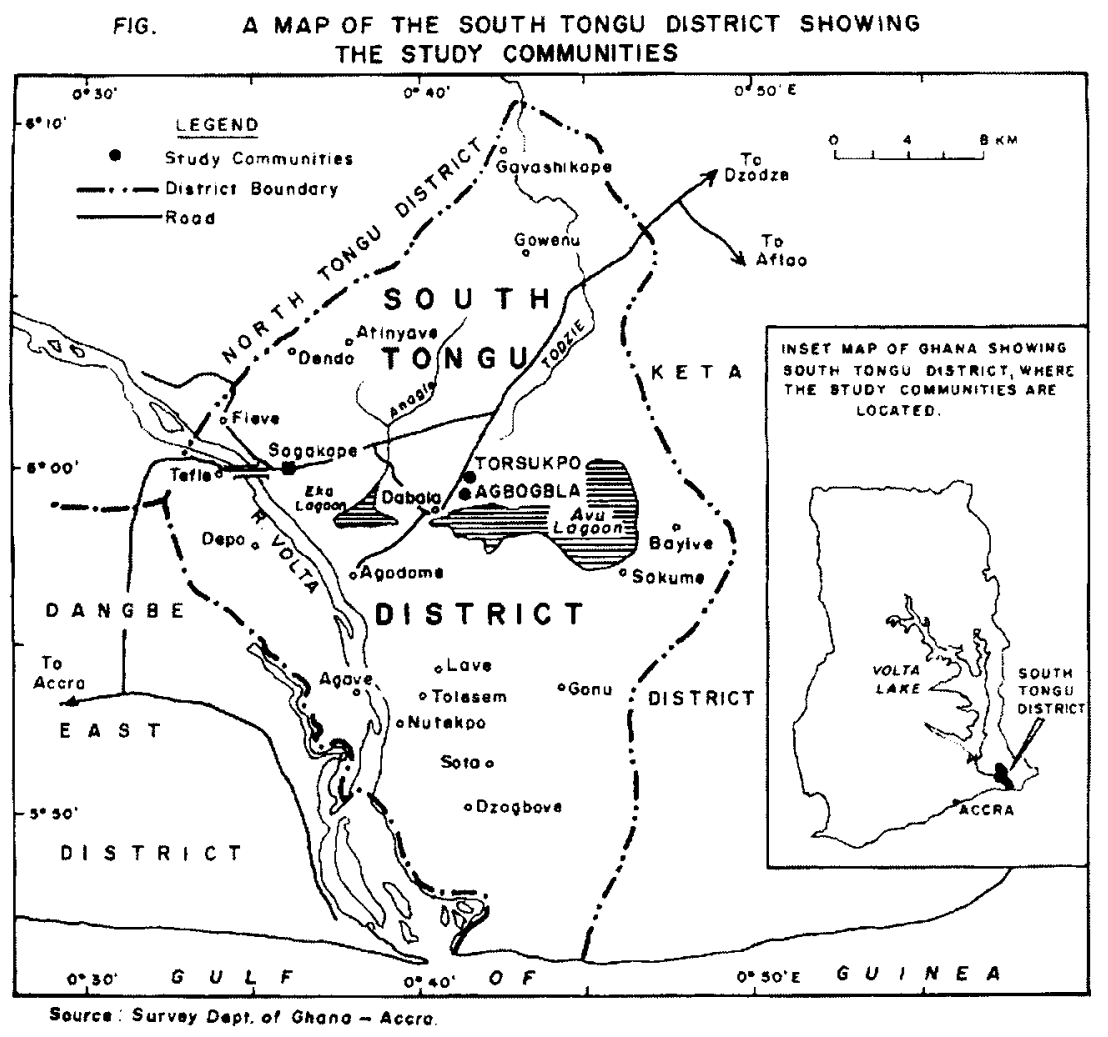

Figure 1. A map of the study area showing the study communities 

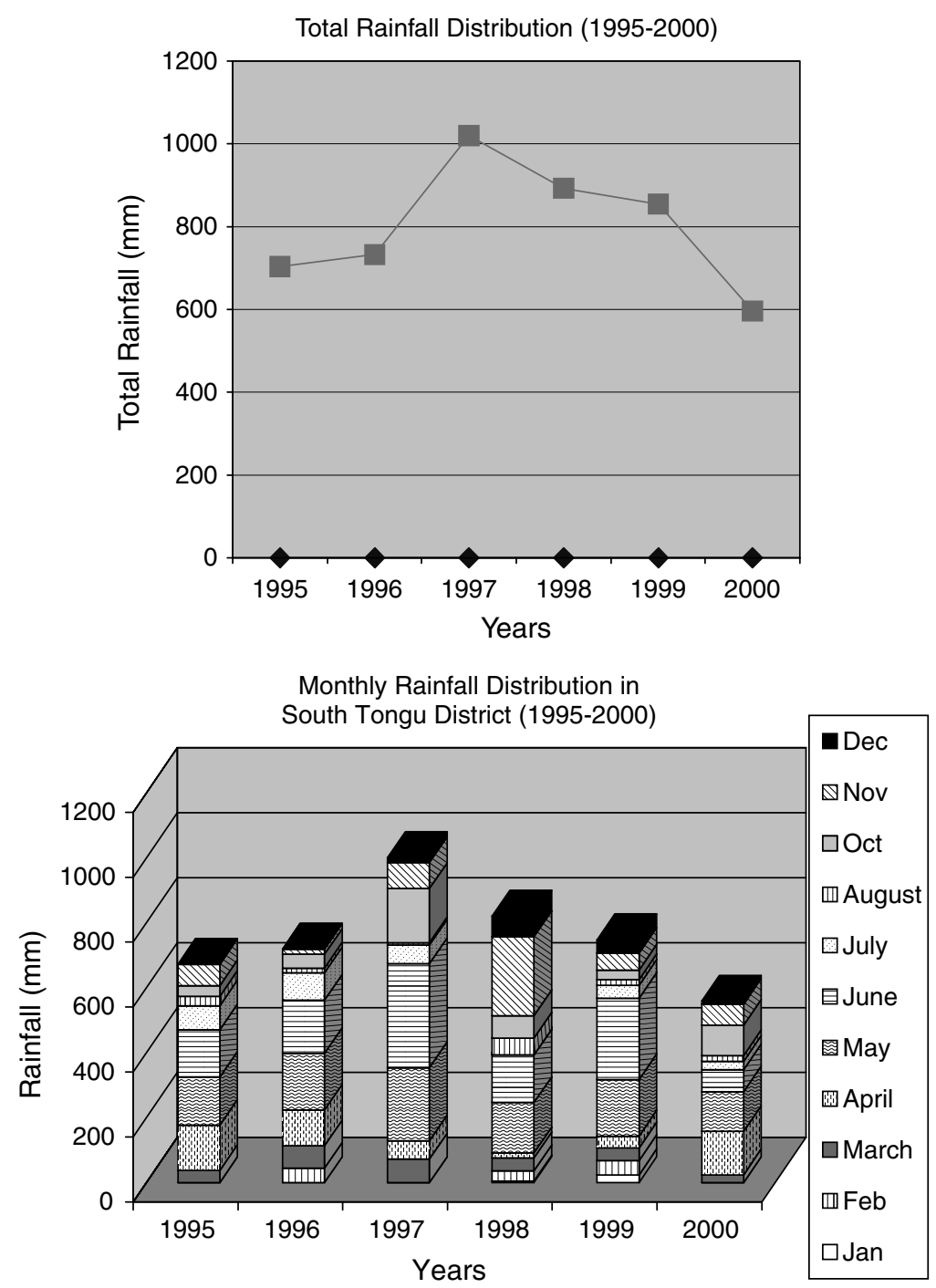

Figure 2. Annual Rainfall Distribution in South Tongu District (1995-2000). Source: Data Compiled from Meteorological Records, South Tongu District Agricultural Office, Sogakope

enhancement of agricultural productivity as a step towards revamping the local economy and improved livelihood has also been brought to the fore. These activities are carried out under several projects. One example is the Ghana Wetland Management project (see Anderson, 1998, for a detailed discussion), from which some communities in the district are benefiting. In addition, the District Assembly under what is popularly referred to as village infrastructure projects (VIPs) is also planning the introduction of catchment planning and small-scale irrigation ${ }^{2}$ in some local farming communities. Whereas such initiatives auger well for rural poverty alleviation, certain land-use related issues (for example property rights), which intricately relate to the activities spelt out, must not escape attention, if the salvation being

\footnotetext{
${ }^{2}$ Village infrastructure projects (VIPs) being carried out by District Assemblies throughout Ghana are being funded by the Government of Ghana, the World Bank, IFAD, KFW and District Assemblies. VIPs are concerned with rural poverty alleviation and capacity building and are considered the primary vehicle for achieving accelerated rural development.
} 
envisaged under such efforts is to be realized. For example, Gyasi noted following his studies on farming systems and tenurial relations among the Ayigbe and Ewe communities in Ghana that the usurious sharecropping and land renting arrangements, whereby tenants have access to farming land, constitute a major factor that compels these and other farmers to overexploit the land (Gyasi, 1997, p. 87).

The above observation seems to blend into findings from a recent study undertaken in the district, which revealed that prevalence of certain customary tenancies (as components of the local social institutional structure) represent potential barriers to effective land husbandry by settler farmers (South Tongu District Assembly, 1996; Koku, 2001). Along with this, other aspects of the local institutional structure, for example, lack of effective co-operative groups and weak co-ordination among local authorities and resource users, have also contributed to undermine the enforcement of rules governing natural resource use. These issues could have far reaching implications if not tackled urgently. It is therefore imperative that district authorities take necessary steps to ensure that these issues are not overlooked, especially at this time when efforts are being made to address problems of environmental management and improved livelihood in the district.

By drawing on some findings from a recent small-scale survey conducted in two communities (Torsukpo and Agbogbla) of the district, this paper seeks to (i) highlight how the prevalence of certain customary property regimes, notably abunu-abusa (sharecropping), present a challenge for effective natural resource conservation in the area; (ii) examine organizational and co-operative group action - focusing on its obstacles and potentials in serving farming and natural resource management purposes in the communities - and (iii) discuss and recommend some potential strategies that may help improve the capacity of local institutions for effective natural resource management. Central to such a strategy will be the promotion of multipurpose co-operatives as a way of organizing local people into productive entities to alleviate marginalization and difficulties encountered with regard to access to factors of production.

\section{THE STUDY AREA}

The study area (Torsukpo and Agbogbla) lies in the South Tongu District ${ }^{3}$ in the Volta Region of Ghana. Torsukpo has an estimated population of about 123 inhabitants (GWSC-Water and Sanitation Study, 1992) made up of (migrant) settler-farmers from neighbouring communities and Districts, whilst Agbogbla is estimated to consist of about 120 inhabitants. The vegetation of the surrounding landscape on which the people depend for their subsistence falls under what is generally described as the interior wooded savannah (Koku, 2001, pp. 311-313). This vegetation type is mostly characterized by grasslands interspersed with shrubs and tree species, notably neem (Azadirachta indica) and acacia (Acacia farnesiana). Also of relevance to the economic life of the people are the swampy areas that lie close to the Avu Lagoon. Some mangrove vegetation is found in the wetland (swampy) areas. The main water body, which provides the bulk of water needs for the people, is the Avu Lagoon.

The topography of the area is generally low lying by virtue of its location within the coastal plains. The geological formation of the area is generally classified under acidic gneiss and schist. Alluvial deposits are also found to some extent in some areas. Soil types in the area

\footnotetext{
${ }^{3}$ This is one of the poorest decentralized districts in the Volta Region of Ghana. It lies in the southern part of the Volta Region, between latitude $6^{\circ} 10^{\prime} \mathrm{W}, 5^{\circ} 45^{\prime} \mathrm{W}$ and longitude $0^{\circ} 30^{\prime} \mathrm{N}, 0^{\circ} 45^{\prime} \mathrm{N}$. It shares borders with the North Tongu District in the North, Akatsi and Ketu Districts to the East, Dangbe West District of the Greater Accra Region in the West and the Gulf of Guinea in the South. It has a total land area of $820 \mathrm{~km}^{2}$. The district comes under the influence of the southwest monsoons twice a year thereby giving it a double rainfall regime with mean rainfall varying from $100 \mathrm{~cm}$ along the coast to $150 \mathrm{~cm}$ in the interior. Mean monthly temperatures range between 24 and $30^{\circ} \mathrm{C}$ in the coolest and hottest months respectively.
} 
have been categorized into two, namely adaoyibi association, and sogakope-pejeglo association. The former developed mainly on alluvial deposits laid down in a former delta of the Volta. If drained effectively, these soils are considered suitable for vegetables and rice, but they are also suitable for pasture. The latter soil category (sogakope-pejeglo) is suitable for the cultivation of cassava and pasture for grazing (South Tongu District Assembly, 1996). Being predominantly agrarian, the inhabitants of the community depend mainly on the land and water resources for subsistence farming, fishing and distillation of local gin (akpeteshie). Among crops cultivated are cassava, maize and sugarcane. The cultivation of the latter is enhanced by the availability of swampy areas, and it provides the bulk of raw materials needed for the local distillery - the dominant occupation of the people.

With respect to climate, comprehensive data for the study area (Torsukpo and Agbogbla) is unavailable, thus necessitating some sort of approximation. The study area lies about $8 \mathrm{~km}$ to the east of Sogakope, where the weather station is located. Given the study area's close proximity to this station, it is assumed that climatic conditions here will not differ markedly from what obtains in the study area. The general rainfall patterns at Sogakope weather station are irregular (Figure 2) and relatively scanty. This affects agriculture since farming activities are mainly carried out under rain-fed conditions.

\section{DATA AND RESEARCH METHOD}

Data inputs for the paper were derived from both secondary and primary sources. The secondary data were generated from published materials-selected reports and journal articles that touched upon the theme of the paper. The primary data, on the other hand, came from questionnaire survey and focus group discussions (FGDs) held in Torsukpo and Agbogbla respectively. The aim here is to add a practical dimension and also to make findings context specific and reflective of reality. The two villages referred to here are small farming communities located about $2-3 \mathrm{~km}$ west of Dabala. They comprise about 35 households each varying in composition between three and nine members. To facilitate the primary data collection in Torsukpo, households in the community were identified and compiled into a serially numbered list. By adopting systematic random sampling (Argyrous, 1997; Nachmias and Nachmias, 1996), 30 respondents (18 males and 12 females), representing $24 \%$ of the total population, were selected. These were drawn (with a random start) from 15 households by selecting two persons, including at least one female (where possible), from every second household on the list.

To elicit relevant information on institutional issues pertaining to natural resource management, questions relating to prevailing customary communal property regimes (e.g. forms of tenancies, rules and conditions which govern allocation, land administering authorities etc) were formulated. Other issues included on the questionnaire relate to respondents' opinions regarding utilization of labour groups for land preparations (clearance), whether any organization has offered support to aid the management of natural resources and also institutions which they consider capable of intervening in tenancy issues in the communities. Responses to these issues were analysed to form bases for drawing inferences. Further, by employing the use of statistical approaches relationships between some parameters were examined. For example, the chi-square statistic (Nachmias and Nachmias, 1996) was applied to examine whether there is any association between respondents' gender and preferred strategy for improving of tenancies. It guards against the weaknesses involved in interpreting chi-square results based on small samples, by further subjecting the data to Cramer's $V$ test. Cramer's $V$, as with most measures of association, ranges between zero (no association) and unity (perfect association). Although 
there is no direct interpretation of any particular value of $V$ between zero and unity, anything under 0.1 is considered very weak (see Argyrous, 1997, pp. 319-324).

The study design took into consideration the fact that the majority of the population are either illiterate or made up of people who may, for some reason, not feel disposed to fill in the questionnaire themselves. The administration of the questionnaire thus took the form of interviews, as opposed to self-administration. Further, as a general guiding principle the survey was restricted to respondents within the age bracket of 17-60 years. The underlying reason was twofold: first, these were considered the most active workforce in the communities; and second, they were old enough to provide relevant responses to the issues addressed by the study. Last, in addition to the questionnaire survey carried out in Torsukpo, a focus group discussion was held with 18 people, made up of elders, farmers, youth and so on, at Agbogbla. With permission from the discussants, proceedings were audio-taped and later transcribed into short notes. This helped to further clarify important issues and complement data generated from the sources noted above. In-depth interviews were also carried out with the district development-planning officer in Sogakope, as well as with other key persons who, by virtue of their work, are well informed about the subject of the study.

\section{INSTITUTIONS VERSUS ORGANIZATIONS: A CONCEPTUAL OVERVIEW}

Institution is a widely used contentious concept that is yet to receive a universally acceptable definition. Like the concept 'sustainability', it is open to several subjective meanings-most of which can be contested because of its vagueness. In contrast to the view shared by some scholars that the two concepts can be used interchangeably (Uphoff, 1986, 1992), others maintain that a clear distinction between institution and organization is necessary if ambiguities are to be minimized (North 1990"; Ostrom, 1992). Thus, stated opinions over such conceptual issues are varied. For example, while the observation of Boesen et al. (1999) that the inter-changeable use of the concept contributes to the confusion may tend to support the latter school of thought, valid reasons may arguably be put forward for the former position. Institutions, in some respects, are categorized in two (North, 1990): (i) formal, comprising constitutions, laws and property rights, or (ii) informal, consisting of sanctions, taboos, traditions and codes of conduct. At the same time, institutions may also involve political bodies (political parties, the senate, a city council, a regulatory agency), economic bodies (firms, trade unions, family farms, cooperations, rural banks), social bodies (schools, vocational training centres) etc.

North further distinguished institutions from organizations noting that organizations, like institutions, provide a structure to human interaction: this structure consists of human beings, whiles the other is composed of rules, laws etc. Ostrom (1992) also makes some distinctions. She observes that an institution is simply 'a set of rules actually used (the working rules or rules-in-use) by a set of individuals to organize repetitive actions that produce outcomes affecting those individuals and potentially affecting others. Hence, an irrigation institution, for instance, has been considered to represent the set of rules for supplying and using water in a particular location' (cited by Boesen et al., 1999, p. 116). However, with reference to the visibility of organizations, she observed that 'organisations are visible and measurable (consisting of human beings), while the rules in use by the organisations consist of common knowledge' (cited by Boesen et al., 1999, p. 116). It is evident from the

\footnotetext{
${ }^{4}$ North (1990) defines institutions as the rules of the game in a society or, more formally, the humanly devised constraints that shape human interaction. In consequence they structure incentives in human exchange, whether political, social or economic.... Institutions reduce uncertainty by providing a structure to everyday life. They are a guide to human.
} 


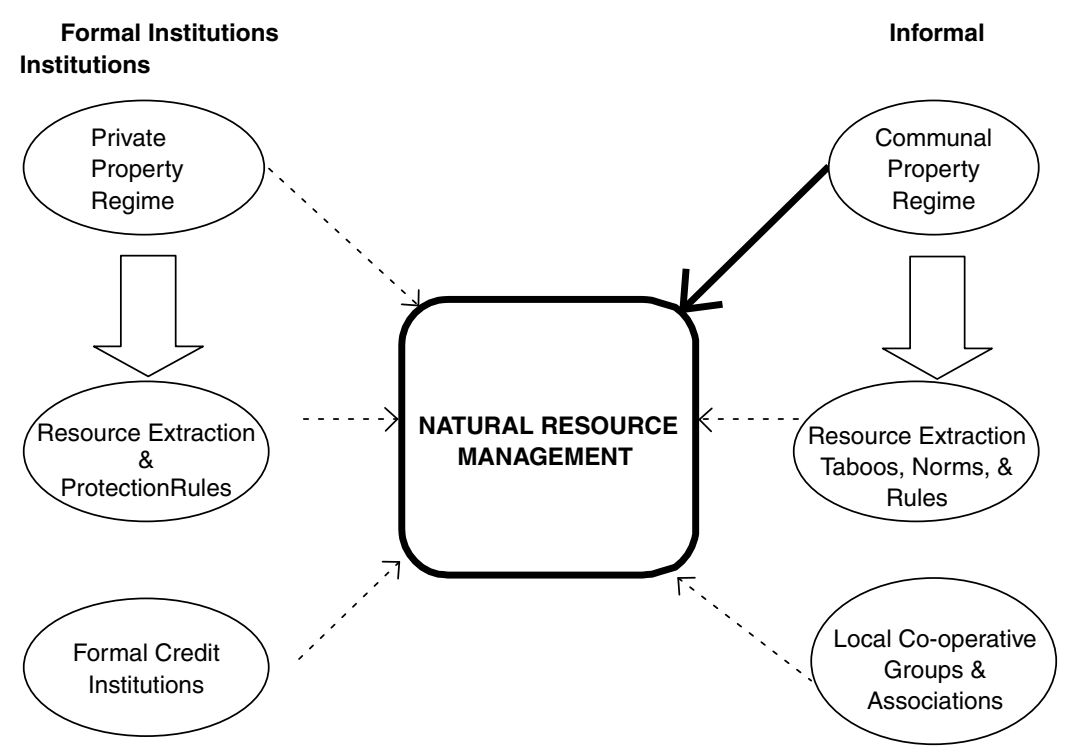

Figure 3. Domain within which the concept is applied in the present study area

above that the two positions can be contested at length, depending on the standpoint from which one views the application of the concept.

It is not the intention of this paper to delve into the intricate theoretical debates surrounding the concept, since that may unduly prolong and blur the main objective of the paper. Nonetheless, to maximize the readers' understanding of issues presented in the subsequent sections of the paper, the present discussions will be based on a mix of the two-formal and informal. The core elements carved out to constitute the domain within which the concept is applied are shown in Figure 3.

\section{Institutions and natural resource management in the south tongu district}

Given the overlapping role played by local institutions in natural resources management, the treatment of the subject in this section has been handled from both formal and informal perspectives. A short overview on aspects of communal resource regime of the study area is presented, highlighting weaknesses and strengths of the study areas tenurial regime. To save space, significant details are not incorporated here, more so when these have already been published elsewhere (Koku, 2001). This is followed by discussion of other relevant institutional issues noted in Figure 3.

\section{Customary property regime}

Every society, no matter what the level of development of its productive forces, has in existence principles or institutional arrangements, which govern the use of its land resource base and other natural resources therein (Songsore, 2001). Natural resources in the South Tongu District have until recently been managed largely as common property, with little control by formal institutions (laws and regulations). Traditionally, land under the common property regime is held in trust for the people by chiefs, clan and family heads, who, as custodians of the land, are expected to administer the land in such a manner that the future access to these resources by those alive and others yet unborn will be guaranteed. As such, access to and control over land is governed largely by customary tenancies, which spell out various rules and conditions under which land should be allocated in communities. However today, the tenure arrangements, which govern the acquisition of land in and 


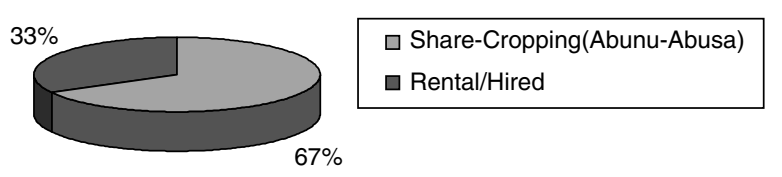

Figure 4. Conditions underlying respondent's land holdings in Torsukpo

around the district capital (Sogakope), could be described as a mix of customary (indigenous) and formal (individual) tenancies. A combination of economic and demographic processes may partly help explain the gradual shift.

The acquisition and allocation of land in the two study communities (Torsukpo and Agbogbla) is governed by communal property regimes. Under this, four main modes of land acquisition have been identified-namely family, leasehold (long-term), personal and abunuabusa (share-cropping) ${ }^{5}$. In principle, these tenancy arrangements are meant to facilitate access to land, provided there is willingness on the part of the potential land acquirer to comply with the rules and regulations spelt out by custodians (chiefs and elders) and other landowners.

Whilst the existence of such arrangements makes some sense and further supports the claim that customary tenancies, especially in rural areas, are put in place for the benefit of all, some ramifications of the system (as this paper seeks to point out) discriminate against non-indigenes. For example, based on field survey in some communities of the South Tongu District, Koku (2001) noted that the equity (fairness) of the abunu-abusa system can be questioned, especially when one considers security of right holders. Using a household questionnaire survey as well as focus group discussion, 30 respondents in Torsukpo (the majority of whom were tenant farmers) were interviewed over a range of issues related to tenure and natural resource management.

Being predominantly settler farmers, they acquired their landholdings under either of the

\footnotetext{
${ }^{5}$ This is a system that is commonly applied when allocating land to tenant farmers. It entails an arrangement whereby crops produced are shared in proportions of $1: 1$ and $1: 2$ respectively between the landowner and the tenant.
}

two main categories of non-permanent customary usufruct tenancy arrangements: (i) abunuabusa (share-cropping) and (ii) rental/hiring. In a few exceptional cases, where people could acquire land directly from local chiefs, most of the land acquisitions were made through family and clan heads under nonpermanent tenancies. Asked during the survey to indicate arrangements governing their allotments, 20 of the respondents indicated having acquired their lands through abunu-abusa, whilst the remaining 10 obtained theirs under rental/hiring arrangements (Figure 4 ). The former system entails an arrangement whereby crops produced by tenant farmers are shared in proportions of $1: 1$ and $1: 2$ respectively between the landowners and the tenant, whilst the latter (rental/hiring) involves paying a certain sum of money annually to landowners, but subject to changes.

The survey showed that, under these usufruct (use) rights, beneficiaries feel rather insecure. As such, in spite of their willingness to undertake tree planting (given their recognition of the importance of trees), they would only do so if the tenurial regime put in place could guarantee some long-term security to enable them reap the benefits of any long-term investment on their allotments. Moreover, it has also been intimated that some landowners feel rather apprehensive to find tenants planting trees on their allotments, since this is perceived as a crafty attempt to lay permanent claims to the land.

The impact of the abunu-abusa on tenant farmers in Ghana as illustrated by this case is not an exception. Similar observations have been made to support this claim. Gyasi in his recent studies on strategies of sustainable farming among some Ayigbe and Ewe tenant 
farmers in Ghana (Gyasi, 1997) noted that the share-cropping and land renting arrangements by which the tenants usually have access to farming land (Gyasi, 1976; Gyasi et al., unpublished) is a major factor that compels them to overexploit the land. As in the case of the groups studied in the South Tongu District, Gyasi noted that typically one-third or even half of the maize and cassava cultivated by the tenants goes to the landowners. To minimize and also adapt to losses incurred under such conditions, tenants intensify work on their farmlands in expectation of greater harvests - a practice that inadvertently results in overexploitation.

Based on this and other experiences noted elsewhere, it becomes clear that although common property regimes can be considered to provide control mechanism for land resources, they do not seem to do so in all cases. To rationalize resource use behaviour among tenants, one would expect that in the face of such uncertainties, a mutually satisfying resource use and extraction rules be put in place and clearly spelt out. However, this has not been the case in all communities, thereby rendering regulation of resource extraction difficult. In the case of the study area, absence of an effective resource extraction regulations and policies has rendered control of overexploitation difficult. As a consequence rampant extraction of fuel wood from surrounding landscapes to feed the thriving local gin (akpeteshie) distillery is on the increase. This scenario tends therefore to support the view held by some that many common-pool resources are degenerating into de facto open access regimes due to lack of effective institutional arrangements and nonconformance to rules.

While not attempting to claim on the basis of the above that the promotion of private tenancies in rural areas could constitute a panacea for sound land husbandry, it may equally be illusive to assume that local institutions are best equipped to provide the needed salvation. To encourage proper land husbandry it may be more desirable to ensure that land policies and management strategies are guided towards addressing problems of (in)security (whether dealing with private or communal tenancies), since this appears to represent the crux of the issue.

\section{Co-ordination among local authorities, rights and enforcement of natural resource management rules}

Institutions, by whatever definition, are human constructs and can be altered if only there is willingness and co-operation among beneficiaries and stakeholders of an existing system. In rural development practice, in any effort towards changing an existing social order, a number of issues have to be grounded in a clear understanding of several issues. Some of these may include rights and/or powers to administer, control and enforcement of resource use rules, identification of actors and stakeholders of the system in question and establishing co-operation among stakeholders through negotiations (dialogue) and in a manner that will provide some appreciable degree of mutual benefits.

A seemingly crucial factor, which often features in the field of natural resource management, is the issue of rights and power. Bromley (1991) clarifies issues concerning rights, noting that

...a right is the capacity to call upon the collective to stand behind one's claim of a benefit stream. Rights only have effect when there is some authority system that agrees to defend the right holder's interest in a particular outcome. Rights are not relationships between people and an object, but are rather the relationships between individuals and others in respect of that object. They can only exist where there is a social mechanism that gives duties and binds individuals to those duties (quoted from Kumah, 2000, p. 44).

If absence of effective compliance with resource use rules combined with unfavourable tenancies are some of the local institutional problems 
that undermine resource use in the study area, then the need for a social mechanism that gives duties and binds individual to those duties, as highlighted in the above quote, calls to attention two areas where local authorities may take action: (i) the need for local authorities to see themselves as agents who through participatory decision making could best address the issue of sustainable natural resource management in their communities and (ii) that it is important to have some authority system that defends the interests of both right holders and resource users.

In almost all parts of rural Ghana, the powers to formulate institutions (rules and regulations), control, allocate, protect and even mediate in conflicts surrounding resource use rest on traditional authorities (chiefs, clan and family heads) and local authorities (in this context, District Assemblies). For example, as a result of the authorities conferred on them, traditional leaders in Ghana have, historically, been seen to exercise powers and rights to identify and set aside certain places in rural landscape for religious reasons. Such practices, although crafted in religious beliefs, represent indigenous strategies for resource protection. Ntiamoa-Baidu (1991, 1995) identified three categories of indigenous strategies that advertently or inadvertently conserve biodiversity in Ghana. These include strategies that seek to

(i) protect particular ecosystems or habitats (such as sacred groves, royal burial grounds, sacred rivers),

(ii) protect particular animal or plant species (such as totems and tabooed species) and

(iii) regulate exploitation of natural resources (such as close seasons for harvesting or hunting).

Sacred groves, such as the Tengbama in the Upper West Region of Ghana (Songsore, 2001), the Malshegu in Northern Ghana (DormAdzobu, 1991) and others such as the Kpabu-ve,
Lawuta-ve and Tomgbome in the Kpando District of Ghana are a few examples, which today may be considered as traditional initiatives that fall in line with the objectives of biodiversity conservation. Rules were formulated to forbid encroachment into such places and violators were punished. As a result, these places have been characterized by original (indigenous) species of plants and animals. We would not digress into the depths of such protected places in this particular paper. They will be dealt with elsewhere. However, their mention here is relevant, as it demonstrates that local authorities have the capacity to formulate institutions for the promotion of sound environmental management if the will is there.

With the example of co-operation cited above, it would be out of place to think that traditional authorities (chiefs, clan and family heads) would not be able to co-operate with local authorities-District Assemblies (DAs) and relevant decentralized departments - to intervene in resource management in the district. Since the decentralization process took effect in 1988, District Assemblies throughout Ghana have been brought closer to the rural folks in their activities. Following this shift in governance, the status of DAs has changed from being mere conveyers of centralized (preformulated) decisions and plans to that of local level bottom-up decision makers. As a consequence, rural folks throughout Ghana see them as agents of change as far as matters relating to their development are concerned. In line with this perception, as the survey reveals, rural folks expect them to play some intervening roles in addressing issues relating to land based resources. This belief has been made evident, for example, in Table 1.

When asked during the survey to suggest strategies for improving the tenancy situation in the study area and also to minimize marginalization of vulnerable groups, the respondents articulated three main categories of strategies in response to the land question. These include the expectation that (i) land must be allocated among siblings of land owning 
Table 1. Respondents' suggested strategies for improving the tenure regime in Torsukpo (percentages in parentheses)

\begin{tabular}{|c|c|c|c|c|c|c|}
\hline \multirow{3}{*}{$\begin{array}{l}\text { Suggested interventions (changes) in tenure regimes } \\
\text { Land must be allocated among siblings irrespective of } \\
\text { gender }\end{array}$} & \multicolumn{4}{|c|}{ Gender groups } & \multicolumn{2}{|c|}{ Totals } \\
\hline & \multicolumn{2}{|c|}{ Males } & \multicolumn{2}{|c|}{ Females } & & \\
\hline & 0 & $(0)$ & 3 & $(10)$ & 3 & $(10)$ \\
\hline $\begin{array}{l}\text { District Assembly should intervene and negotiate with } \\
\text { landowners for favourable tenure terms }\end{array}$ & 13 & $(43)$ & 6 & $(20)$ & 19 & $(63)$ \\
\hline Land should be sold (commercialized) & 5 & $(17)$ & 2 & $(7)$ & 7 & $(24)$ \\
\hline No suggestion & 0 & 0 & 1 & (3) & 1 & (3) \\
\hline Total & 18 & $(60)$ & 12 & (40) & 30 & (100) \\
\hline
\end{tabular}

Source: Questionnaire Survey in Torsukpo, 2000.

Chi-square $\left(\chi^{2}\right)=\Sigma\left(f_{\mathrm{o}}-f_{\mathrm{e}}\right)^{2} / f_{\mathrm{e}}$

$\chi^{2}=6.92$. Df $=3$ at 0.10 level of significance. $N=30$.

Cramer's $V=\sqrt{x^{2} / N(k-1)} V=0.48$ where $k$ is either the number of rows or the number of columns, whichever is smaller.

families regardless of gender, (ii) the District Assembly should intervene and negotiate on behalf of tenant farmers with landowners for favourable terms and (iii) access to land should be made available through outright sales (commercialization). The survey used Cramer's $V$ statistical test to examine whether there is any association between the gender of respondents and suggested strategies. The results (i.e. Cramer's $V=0.48$ ) do suggest an existing association. For example, with the exception of one female, who declined to offer any suggested strategy, the opinion that District Assemblies should intervene stands as the most popular, representing $63 \%$ of all responses with more than half $(43 \%)$ of the responses in favour of this view expressed by males, leaving only $20 \%$ for females. The high response articulated in favour of the District Assembly may be explained in numerous ways, but the most probable is that the people perceive the assembly as an authoritative local institution and a responsible adjudicator that could intervene and negotiate with elders in matters relating to land. Whiles this observation may well reflect the confidence, respect and trust reposed in the assembly, it equally suggest two important issues that have relevance for rural development administration: (i) that public perception of an institution may affect co-operation and (ii) that effective cooperative and performance of a local institution may lie in how it mirrors itself in the eyes of those it serves.

With regard to the issue of land commercialization (connoting individual ownership), almost $24 \%$ of the responses supported the view as opposed to the opinion that communal ownership could provide some redemption. However, this view needs to be cautiously approached, since no conclusive evidence has been found to prove that privatization provides security guarantees in all cases (Songsore, 2001). The suggestion that lands be sold out to individuals only reflects the wishes of a few relatively wealthy respondents, who conceive outright purchase of land as a way of securing their tenancy positions. Under privatization, it is most likely that a large number of the settler farmers in the community may find their conditions worsened - many may not have the resources (finances) to respond to the market forces that may be generated under privatization. Moreover, an open commercialization of land, if allowed to take place, may constitute violation of the traditional rules (institutions) governing land, which is supposed to be held as commons. 
Thus, such an attempt in an agrarian community like the study area is likely to be met with fierce resistance. Further to that, outright sale of lands as is being practised in some periurban communities triggers rising cost of land. Considering the proximity of the study area to Sogakope (the district capital) and other larger towns, outright sale of lands may in course of time attract the interest of developers and investors to drift to such areas. A potential consequence of this is that smaller settler farmers may find their positions more insecure when faced with competition with developers. The effect of this, especially that relating to rising cost of land, is already being witnessed in Sogakope (the district capital) and its immediate surroundings. Alhassan's findings from studies in the New Juabeng District of Ghana lend some credence to this assertion. Based on his findings in the New Juabeng District, he states

There now exist a high prevalence of private land ownership, a development that has allowed farmers to be bought out by other land developers. Many landowners readily sell their lands, sometimes without informing the tenant farmers who use and pay for its use through the sharing of farm produce. The take over of farms and other agriculturally productive lands has been endorsed fully by landowners because they earn more money from sale of lands to residential, commercial and industrial developers (Alhassan, 1999, p. 62).

This observation and others documented elsewhere on the private versus communal ownership of land further support an earlier position documented on the debate - the crux of the issue lies in the provision of security (Koku and Gustafsson, 2001, p. 137) and not necessarily in the effectiveness of one tenancy over the other.

Another critical issue that arose was the fact that only females offered the response land be allocated to siblings irrespective of gender. A further probe into reasons for this suggestion was quite insightful. Adherents to this position believe that since the prevailing traditional tenure regime is built on levels of political hierarchy of ethnic groupings (kinship-clan and lineage), whereby decision-making powers are vested in male custodians of land, the plight of females tends not to be adequately taken care of. In view of this, it was felt that if there is an alteration in the existing regime, whereby equal decision-making status could be granted to female siblings, easy access to land by people such as female migrant settler-farmers would be facilitated. This argument is likely to be contested, based on varied experiences that may be gathered elsewhere. Nonetheless, it provides food for thought.

To sum up, three key issues have emerged form the preceding discussion: (i) that the share-cropping tenancy arrangement constitutes a disincentive to effective conservation practice; (ii) that traditional authorities can regulate and protect resources through development of control mechanisms, notably norms, rules etc, and also that possibilities for co-operation between local authorities and traditional leaders be promoted and (iii) that equitable disposal of land and control of resource use must constitute a significant part of any strategy that seeks to rejuvenate economic production in the district. However, what possibilities are available for District Assemblies to build co-operation with other authorities to accomplish such a task? The next section reviews some policy provisions and highlights some possible steps, including co-operative group formation among strategies that may help address the problem.

\section{POLICIES AND POSSIBILITIES FOR BUILDING CO-OPERATION}

\section{Policy provisions}

Policy directives can be tapped as starting points for initiating action between District 
Assemblies in general and traditional authorities under them. It suffices to state at this point that the Government of Ghana, for the first time in the history of the country, was able to put in place a National Land Policy (NLP) in 1999, which touches on several issues that relate to sustainable use of land and natural resources in the country. Drawing therefore on relevant provisions made in the policy (Ministry of Lands and Forestry, 1999), the very first step towards formulation of plans to address the frequently reported problem of access to and (in)security of tenure can be pursued. For example Sections 4.2 and 4.3 of the new policy provide guidelines for facilitating equitable access to land; and also security of tenure and protection of land right, respectively. Regarding facilitating equitable access to land, Section 4.2(a) declares as follows: 'an individual can have access to land in any part of Ghana, provided that: (i) land is available for disposal in that part of Ghana, where he seeks to have access to the land; (ii) he agrees with the landowner to adhere to the covenants and other customary practices governing the disposal of the land; (iii) he undertakes to put the land to a use, which conforms to land use plans for the area and to the principles of sound land use and management'.

Further to this, Sections 4.2(c) and (f) make respective provisions, which underscore the role of District Assemblies (DAs) in this task. Section 4.2(c) states that 'District Assemblies in conjunction with landowners should prepare planning schemes for all land uses to facilitate dispositions of land for development', while Section 4.2(f) declares that 'District Assemblies may negotiate for land for development purposes at concessionary prices or as a gift, but all such grants should be properly documented and processed'. Given the authority vested in DAs under the Local Government Act 462 (1994) to enable them play a crucial role in the implementation of the National Environmental Action Plan (EPA, 1991), the South Tongu DA is in a better position to begin negotiations for an improvement in access to and control over land. Provisions made in the National Land Policy have already supported such an effort. For example, for vulnerable and migrant farmers such as those found in the study communities (Agbogbla and Torsukpo) in the South Tongu District, the DA may take advantage of provisions made in Sections 4.2(c) and (f) to negotiate with landowners to facilitate their access to land. The importance of this is further underscored by provisions in Section 4.3(b), which identifies, among others, the need to consider conservation of natural resources and land as part of land disposal decision-making.

Leaving the politics of negotiations aside for the moment, these provisions have at least provided enough backing for any initial step. For example, for marginal farmers in the district as well as those found in the study area, negotiations could be pursued to organize such people into co-operative groupings to enable them secure access to land for productive activities. The literature notes the Tree Growing Association in West Bengal (and elsewhere in India) as one good example of such an initiative (Bromley, 1991). The association is made up of landless or marginal farmers who are given a block of public land for tree planting under usufruct (use) right regimes. The members are not granted titles in land, but the group is given usufruct rights on the land and ownership rights of its produce. On a greater scale this was an important part of the Chinese multipurpose co-operatives under the people's commune system (Gustafsson, 1984).

Historically, past governments of Ghana have tried to expropriate land for special projects similar to the Bengal case. However, failure in paying compensation to those dislocated and re-settlement of those affected have brought untold hardships, with many consequences. Litigation and court cases involving government authorities and those dispossessed were experienced in Ghana. To avoid this and avert antagonism caution must be exercised that the process is not carried out 
by means of force. In other words, any strategy initiated in line with provisions made in the new land policy must be properly planned through a negotiation process. Since the South Tongu District is endowed with abundant natural resources (land and water resources), the present authors believe that mobilizing labour into co-operative groups may help encourage productive use of the land. The next section exemplifies such possibilities and highlights how they may be pursued.

\section{Co-operatives as panacea for improved socio-economic development: why and how?}

Another vital institutional issue of importance to natural resource management at large, and socio-economic development of the area relate to the possibility of reviving co-operatives for farmers and other resource users. This becomes even more urgent in view of the fact that access to inputs and credit has been identified as one of the obstacles hindering productive land use in the district (South Tongu District Assembly, 1996). Co-operatives constitute an important part of the broader institutional arrangements. They come under various forms - ranging through credit, production, marketing and business, retail, farms or even multipurpose co-operatives. The establishment of co-operatives used to be one of the institutional means by which rural people of Ghana were organized for productive activities between the 1970s and 1980s. However, for several reasons, including lack of political support, lack of market for products and unfair competition from state enterprises (Dadson, 1986), many collapsed. However, in recent times co-operative and productive associations have re-emerged as viable entities of development. Examples of co-operatives (associations) in the district include the Fievie Tree Growers Association, Vume Pottery Women Association, Association of Tailors and Seamstresses, Ghana Private Road Transport Union (GPRTU) etc. To strengthen the activities of these associations, the Department of Co-Operatives (a government department) was set-up to coordinate and facilitate their activities.

In the present era of the country's decentralization process where District Assemblies are given the mandate to plan development strategies that best reflect local circumstances and interests, it might perhaps be useful to reconsider the rejuvenation of co-operatives for the rural folks. The study area with its expanse of land, coupled with its proximity to the vast Avu Lagoon (a fresh water lagoon) is imbued with tremendous agricultural potential. Yet, there are limited effective economic activities that could absorb its labour. Apart from the traditional farming sector and the local gin distillery, which absorb the available labour, access to viable employment sectors is restricted. As a result, migration of the youth to urban areas is on the increase. This results in low land and small-scale industrial productivity and thus low income generation, which ultimately plunges the local economy in a vicious cycle. Declining school enrolment at both primary and secondary levels, a trend that characterizes education in the study area, presents yet another challenge, thereby underscoring the need for co-operative movement.

We shall explain briefly what is implied here. In the study area (notably Torsukpo), school enrolment is low. Drop-out starts occurring after the second and third school years for a variety of factors. Figures 5(a) and (b) are illustrative of the general trend. For students in the junior secondary school (JSS) some of the factors include lack of funds on the part of parents, truancy arising partly from adolescence, non-compliance with discipline and the code of conduct expected of students, and early marriages, among others.

The youth who have not had the chance to attend school (including the drop-outs), as well as those who have not had the chance to migrate to the urban centres in search of jobs, find placement in nowhere else, but in subsistence agriculture. As such, farming tends to represent a significant labour absorbing sector, in addition to distillation 


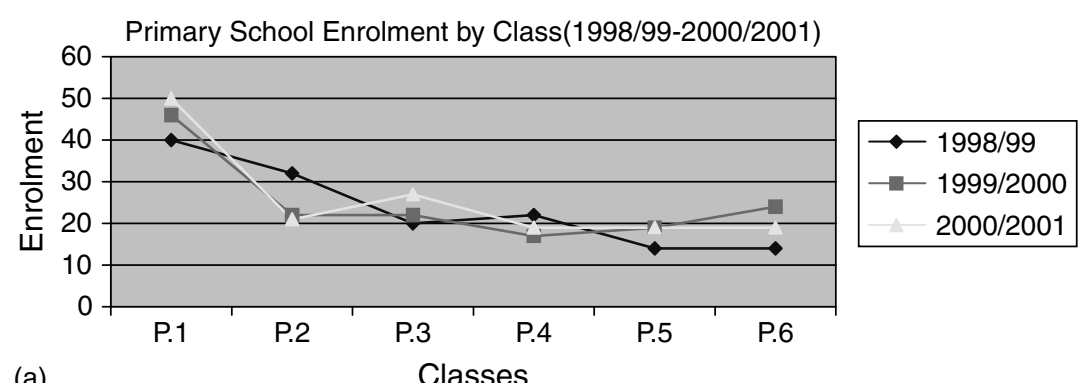

(a)

Classes

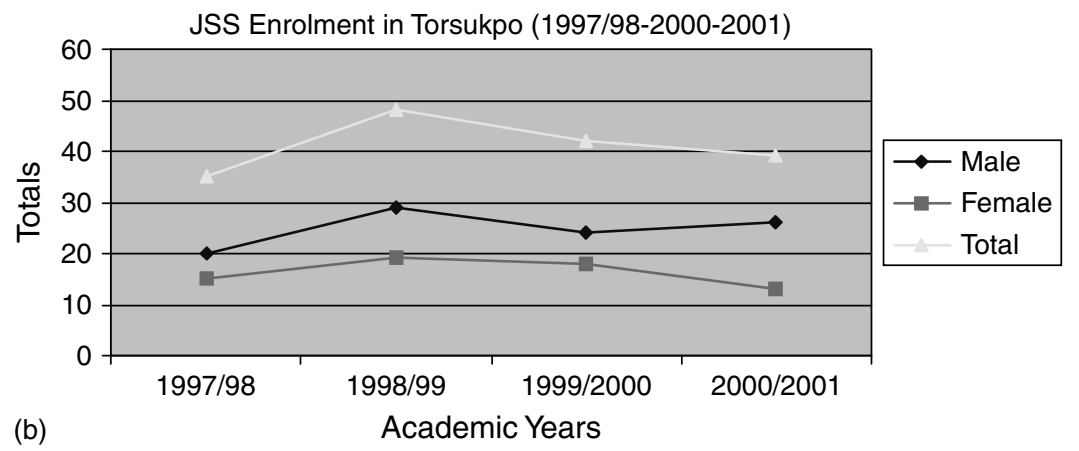

Figure 5. (a) Primary school enrolment in Torsukpo. Source: L.A. Primary School Enrolment Register, Torsukpo.

(b) Junior secondary school (JSS) enrolment in Torsukpo. Source: L.A. JSS School Enrolment Register, Torsukpo

Table 2. Distribution of respondents' method of land preparation in Torsukpo (percentages in parentheses)

\begin{tabular}{lrcrrrr}
\hline \multirow{2}{*}{$\begin{array}{l}\text { Method of } \\
\text { land preparation }\end{array}$} & \multicolumn{3}{c}{ Gender groups } & & \multirow{2}{*}{ Totals } \\
\cline { 2 - 5 } & \multicolumn{2}{c}{ Males } & \multicolumn{2}{c}{ Females } & & \\
\hline Hired labour & 6 & $(20)$ & 9 & $(30)$ & 15 & $(50)$ \\
Family labour & 10 & $(33)$ & 3 & $(10)$ & 13 & $(43)$ \\
Use of machinery & 2 & $(7)$ & 0 & $(0)$ & 2 & $(7)$ \\
Total & 18 & $(60)$ & 12 & $(40)$ & 30 & $(100)$
\end{tabular}

Source: Questionnaire Survey in Torsukpo, 2000.

Chi-square $\left(\chi^{2}\right)=\Sigma\left(f_{\mathrm{o}}-f_{\mathrm{e}}\right)^{2} / f_{\mathrm{e}}$

$\chi^{2}=5.38$. Df $=3$ at 0.10 level of significance. $N=30$.

Cramer's $V=\sqrt{x^{2} / N(k-1)} V=0.42$ where $k$ is either the number of rows or the number of columns, whichever is smaller.

of local gin (akpeteshie), as is the case the Torsukpo and Agbogbla communities. This, and the observation that access to factors of production (e.g. credit, land, capital etc) tends to constrain effective management of natural resources in the communities, provide further ground for the argument that co-operatives may present opportunities for mobilizing the rural folks into productive units for the pursuit of sound economic livelihood in the area.

\section{Co-Operative alternatives}

With little dependence on mechanization, agricultural land preparation in the communities is carried out via three organized means, namely use of family labour, hired labour and 
dependence on use of tractors. Of the three, the use of hired labour dominates, representing $50 \%$ of all responses (Table 2), followed by use of family labour (43\%). However, a common feature that links the two is that they all involve the use of hoes and cutlasses for clearing purposes. The use of machinery (tractors) is insignificant $(7 \%)$, partly due to the high cost involved in utilizing the services of tractor rentals.

Further analysis of the data reveals also an existing association between gender and methods of land preparation (Cramer's $V=$ 0.42 ). Whereas results in Table 2 suggest that the three methods of land preparation are shared by all respondents, the organizational role played by males tended to be more amplified in their responses. Males' responses regarding the adoption of three types of land preparation was $60 \%$, whilst that of females represented only $30 \%$.

However, by and large, it could be deduced from the above data that some tendency to mobilize labour from within has evolved as part of the communities' response and adaptation not only to need, but also to its dynamic agricultural circumstances. This adaptive capability of the people to mobilize (family and others on hired basis) for farm labour purposes may be indicative of existing possibilities for mobilizing the people for co-operate action. Following this logic through, it may be desirable to suggest that the promotion of co-operatives may provide an alternative solution in reviving the socio-economic and cultural life of the communities. This position may be supported, further, by the observation that water resources abound to serve purposes for irrigation - yet, access to credit, capital, easy assess to land (in the case of settlerfarmers) and other production are hard to come by as individuals, thereby placing limitations on effective production. Placing an eye on all the potential resources that abound in the area, the present authors follow the above logic to develop a value-based opinion though that, with the proximity of the communities to water bodies such as the Avu Lagoon, possibilities could be explored to harness such water bodies for irrigation purposes. This, if deemed appropriate, may be amalgamated with other activities (e.g. credit cooperative unions) into what may well emerge as multipurpose co-operatives. Examples of successful co-operative groups and associations exist in Ghana.

Ofei-Aboagye (1998) reviewed activities of several of such organizations in Ghana. Included in the successful cases reported are the Bawku East Women's Development Association (BEWDA) and Kaleo Baptist Women's Development Programme. The former, for example, was set up in 1988. BEWDA covered ten villages in the Bawku East District with each village further subdivided into 33 subgroups consisting of between 10 and 25 members each. It has the following as some of its key features: securing a revolving fund and a seed credit scheme from WomanKind (a British NGO) to provide credit facilities for women's ventures, notably pito (local beer) brewing, malt processing, shea butter processing and various forms of petty trading. Other activities include cultivation of groundnuts, soya beans, rice, onions, sorghum or millet. To maximize recovery rate of loans disbursed under the scheme, carefully designed control measures was put in place. The credit is disbursed as group loans. The women groups act as guarantors for the loans, which are then distributed to members. Women start paying back their loans three months after receipt. If a member defaults on her repayment, the entire group is suspended for the next phase of loan disbursals. This arrangement is considered useful and effective as it encourages all members to supervise deployment of the loan for the intended use and the timely repayment of loans. Therefore, loan recovery is high, estimated at about $100 \%$ (see Ofei-Aboagye, 1998). The British NGO (WomanKind) has sponsored the activities of the association since 1990. 
As with all societies, the South Tongu District (including the study area being discussed in this paper) may be unique in some respects. As prudence would suggest, it will not be desirable and appropriate to pursue the promotion of group action strictly following the example of BEWDA or any other group. Any strategy that may unfold may have to reflect local circumstances and needs. Nonetheless, since we dwell upon existing knowledge to search for the unknown, the success lessons from their strategies may constitute useful guides. A careful formulation of a co-operative strategy would thus serve as a viable productive entity that could even absorb marginalized groups (women as well as poor and settler-farmers) in the area into productive activities. Moreover, given the observation that formal education is not well rooted in the area, as well as the general declining trend in school enrolment (Figure 5), such productive entity may prove useful. The point here is not to imply that formal education is not promising and hence has to be replaced by such activities. Rather the argument being put forward is that co-operatives may serve as alternative safety nets for vulnerable groups, including even those who may not have the capacity to pursue higher academic studies.

\section{How can the District Assembly (DA) facilitate such pursuits?}

It can be said with much certainty that the role of the District Assembly is vital to the success of any initiative to rejuvenate co-operatives in the district. To play the role of a facilitator in the process, the DA could take advantage of provisions made in Sections 4.2(c) and (f) of the land policy to begin negotiations with chiefs and elders in the communities to secure land for the purpose of planning such a multipurpose co-operative activity in consultation with identified stakeholders. Being a poor district, the DA and traditional authorities may not have the needed resources for any largescale activity. As such, it will be desirable if such an initiative can be pursued on a small scale to start with.

Although fears and criticisms have been expressed in certain circles over the involvement of non-governmental organizations (NGOs), they have been instrumental in providing support for local initiatives, especially where resources are inadequate or unavailable. In this regard, the Assembly may solicit the support of NGOs to act as facilitators - at least at the initial stages to alleviate the financial burden. However, caution should be exercised to ensure that NGO involvement does not result in a situation where they become the main drivers and implementers. The role of NGOs must be factored into the strategy as facilitators. This is important in helping beneficiaries to first, inculcate the spirit of self-management, and second, understand from the onset that they are the main actors and must therefore bear responsibility for the planning, operation and maintenance of their co-operative entities. Chepkwony (1987) further supports such a position by drawing out for illustrative purposes cases where dependence of some Kenyan churchled NGOs on external funding agencies had led them to become centralized and detached from the grassroots, leaving the groups they work for with rather precarious and uncertain situations.

The pursuit of the institutional strategies proposed in this paper will without doubt not be problem free. Some initial difficulties are bound to be encountered. Resistance to dispose of land may be met in the initial stages, especially as most lands in the district are under customary governance, with chiefs and elders still holding their positions as custodians of land for their respective people. However, possibilities exist if the negotiation process is tactfully planned by bringing chiefs and elders on board right from the initial stages, and convincing them about the relevance of such ventures. This is where the challenge lies for the local authorities (assembly) - the ability to translate theory into practice. 


\section{CONCLUDING REMARKS}

From the discussion presented above as well as several others documented in the development literature, it has now been widely accepted that institutions (both formal and informal) provide one of the crucial keys to sound environmental and resource management. The only problem is to try to move beyond the theories and rhetoric to practical actions. This could be accomplished by making firm commitments to study and craft institutions that are adapted to the socio-economic and cultural conditions of local communities.

\section{ACKNOWLEDGEMENT}

An earlier version of this paper was presented at the 2001 International Sustainable Development Research Conference, University of Manchester (5-6 April, 2001). Sida (SAREC) is gratefully acknowledged for supporting the research work in Ghana. The views and opinions expressed in this article do not necessarily reflect those of the authors' affiliation or that of Sida (SAREC), the funding agency for this research.

\section{REFERENCES}

Alhassan OA-R. 1999. Urbanization and woodfuel resources in New Juabeng Municipality. Bulletin of Ghana Geographical Association 21: 55-64.

Anderson T. 1998. Wetlands management in Ghana. In The Cornerstone of Development: Integrating Environmental, Social and Economic Policies, Schnurr J, Holtz S (eds). Lewis: Boca Raton, FL; 177-312.

Appendini K, Nuijten M, Rawal V. 1999. Rural Household Income Strategies and Interactions with the Local Institutional Environment: a Methodological Framework. SD Dimensions, Rural Institutions and Participation Service (SDAR) FAO Rural Development Division.

Argyrous G. 1997. Statistics for Social Research. Macmillan Press Ltd.: London.

Boesen J, Maganga F, Odgaard R (eds). 1999. Rules, norms, organizations and actual practices: land and water management in the Ruaha River Basin, Tanzania. In Managing the Globalised Environment: Local Strategies to Secure Livelihood, Granfelt T-R (ed.). Intermediate Technology: London.
Bromley DW. 1991. Environment and Economy: Property Rights and Public Policy. Blackwell: Oxford.

Chepkwony A. 1987. The role of non-governmental organisations in development: a study of the National Christian Council of Kenya (NCCK) 1963-1978. Studia Missionalia Uppsaliensia 43.

Dadson JA. 1986. The co-operative sector and rural development in Ghana. In Rural Development in Ghana, Brown CK (ed.). Ghana University Press: Accra.

Dorm-Adzobu C. 1991. Religious Beliefs and Environmental Protection: the Malshegu Sacred Grove in Northern Ghana, The Center for International Development and Environment (ed.). Washington, DC: World Resource Institute.

Gustafsson J-E. 1984. Water Resources Development in the People's Republic of China. Doctoral Dissertation, Meddelande trita-kut 1035, Royal Institute of Technology, Stockholm.

Gyasi EA. 1976. Population pressure and changes in traditional agriculture: case study of farming in Sesekua-Agbelitsom, Ghana. Bulletin of the Ghana Geographical Association 18: 68-87.

Gyasi EA. 1997. Ability of the farming systems to cope and strategies for sustaining farming. In Environment, Biodiversity and Agricultural Change in West Africa, Gyasi EA, Uitto JI (eds). United Nations University Press: Tokyo; 84-89.

Hinchcliffe F, Thompson J, Pretty J, Guijt I, Shah P (eds). 1999. Fertile Ground: the Impacts of Participatory Watershed Management. Intermediate Technology: London.

Koku JE. 2001. Socio-cultural factors and land degradation in the South Tongu District of Ghana: some implications for resource protection and environmental health. Journal of Environmental Planning and Management 44(3): 309-330.

Koku JE, Gustafsson J-E. 2001. Local institutions and environmental planning in the South Tongu District: reflections on some challenges and prospects for effective resource management. In Conference Proceedings, the 2001 International Sustainable Development Research Conference, Manchester, 2001. ERP Environment: Shipley.

Kumah WKA. 2000. Participation in Local Resource Management: the Case of Agricultural and Forest Land Use in the Jasikan District of Ghana, Masters Dissertation, Department of Geography, Norwegian University of Science and Technology, Trondheim.

Leach M, Mearns R. 1996. The Lie of the Land: Challenging the Received Wisdom in African Environment. International African Institute in Association with James Curry, Heinemann and Oxford: Portsmouth, $\mathrm{NH}$. 
Mearns R. 1995. Institutions and natural resources management: access to and control over fuel wood in East Africa. In People and Environment in Africa, Binns T (ed.). Wiley: Chichester.

Miller D, Ayariga R, Anamoh B. 1996. Grandfather's way of doing. In Sustaining the Soil: Indigenous Soil and Water Conservation in Africa, Reij C, Scoones I, Toulmin C (eds). Earthscan: London.

Ministry of Lands and Forestry. 1999. Ghana National Land Policy. Ministry of Lands and Forestry: Ghana.

Nachmias CF, Nachmias DN. 1996. Research Methods in the Social Sciences. St. Martins Press Inc.

North DC. 1990. Institutions, Institutional Change and Economic Performance. Cambridge University Press: New York.

Ntiamoa-Baidu Y. 1991. Conservation of coastal lagoons in Ghana: the traditional approach. Landscape and Urban Planning 20: 41-46.

Ntiamoa-Baidu Y. 1995. Indigenous Versus Introduced Biodiversity Conservation Strategies: the Case of Protected Area Systems in Ghana (African Biodiversity Series 1). African Biodiversity Support Program. http://www.bsponline.org/publications/showhtml [11 October 2001].

Ofei-Aboagye EO. 1998. Women's Groups and Associations as Partners in Small Enterprises Development in Ghana, report from study jointly funded by Friedrich-Ebert Foundation and National Board for Small Scale Industries, Ghana. Gold-Type: Accra.

Orstrom E. 1992. Crafting Institutions for Self-Governing Irrigation Systems. ICS Press: San Fransisco.

Shah P, Shah MK. 1999. Institutional strengthening for watershed development: the case of the Aga Khan Rural Support Programme (AKRSP) in India. In
Fertile Ground: the Impacts of Participatory Watershed Management, Hinchcliffe F, Thompson J, Pretty J, Guijt I, Shah P (eds). Intermediate Technology: London.

Songsore J. 2001. The decline of rural commons in Sub-Saharan Africa: the case of Upperwest Region of Ghana. In Regionalism and Public Policy in Northern Ghana, Yakubu S (ed.). Lang: New York.

South Tongu District Assembly. 1996. South Tongu District Socio-Economic Survey. SPRING/DoP, UST, Ghana.

Uphoff N. 1986. Local Institutional Development. Kumarian: Hartford, CT.

Uphoff N. 1992. Local Institutions and Participation for Sustainable Development (Gatekeeper Series 31). International Institute for Environment and Development (IIED): London.

\section{BIOGRAPHY}

John E. Koku (corresponding author) and JanErik Gustafsson are based at the Department of Land and Water Resources Engineering, Royal Institute of Technology (KTH), Brinellvagen 28, SE-100 44, Stockholm, Sweden.

Tel.: +4687908611

Fax: +468410775

E-mail: koku@aom.kth.se 